\title{
REVERSE OBLIQUITY FRACTURE OF THE PROXIMAL PART OF THE FEMUR (AO/OTA 31-A3) TREATED WITH INTRAMEDULLARY NAIL
}

\author{
Igor M. Kostić
}

\begin{abstract}
Intertrochanteric fractures of the femur with reverse fracture line are unstable fractures of unique anatomical and biomechanical characteristics, which are surgically treated with extramedullary or intramedullary fixation methods.

The purpose of this study was to evaluate intertrochanteric femoral fractures with intramedullary nail treatment in regard to surgical procedure, complications, and clinical outcomes.

We retrospectively analyzed outcomes of thirty-two elderly patients with AO/OTA 31A3 intertrochanteric fractures of the femur treated by proximal cephalomedullary nails available at our institution, Clinic of Orthopaedic and Traumatology Niš, Serbia, during the period from 2012 to 2020 years. Postoperative follow-up ranged from 12-22 (12.36) months.

Surgical procedures were performed on average 4.45 days after the injury. The average duration of the surgical intervention was 64 minutes. Closed reduction of fracture and internal fixation were achieved in 26 cases. Acceptable anatomical reposition was achieved in 17 cases $(53.12 \%)$, and anatomical reposition in 15 cases $(46.88 \%)$. The mean value of the Harris hip score was 74.66 (65-96), and the mean value of Barthel's activity score was 15.71 (12-20). Fracture healing after intramedullary fixation was achieved in 29 cases, while in 2 cases complications in the form of failure of internal fracture fixation and non-union of fractures $(6.25 \%)$ were noted.

Intramedullary fixation of reverse transtrochanteric fractures (AO/OTA 31-A3) with short or long cephalo medullary nails provides adequate biomechanical conditions for fracture healing in the optimal time period with the possibility of performing a minimally invasive surgical procedure.
\end{abstract}

Acta Medica Medianae 2021;60(4):45-54.

Key words: reverse transtrochanteric fracture, intramedullary fixation, minimally invasive surgery

University Clinical Center Niš, Clinic of Orthopaedic Surgery and Traumatology, Niš, Serbia

Contact: Igor M. Kostić

48 Dr Zoran Djindjić Blvd., 18000 Niš, Serbia

E-mail: igaort@gmail.com

\section{Introduction}

Intertrochanteric fractures continue to be one of the most common causes of high geriatric morbidity and mortality (1). Reverse oblique intertrochanteric fractures are classified by the Orthopaedic
Trauma Association (AO/OTA) classification as A3, and they account for $2-23 \%$ of all trochanteric fractures. This type of fracture may also be divided into three subgroups:

- A3.1 are oblique fractures,

- A3.2 have a transverse fracture patterns, and

- A3.3 are more comminuted with the fracture line involving the lesser trochanter, and are considered the most unstable fractures in this category (2) (Figure 1).

Because of their opposite fracture configuration, which is characterized by the fracture line running obliquely from the proximal greater trochanter to the distal lesser trochanter, reverse obliquity intertrochanteric fractures are unstable with unique anatomical and mechanical characteristics and present challenging fracture to treat whatever implant is used. There are two main types of implant available for the treatment of these fractures, namely, extramedullary and intramedullary implants $(3,4)$. Although the most widely used extramedullary implant is the dynamic hip screw, which consists of a sliding hip screw connected to a plate in the lateral 
femoral cortex, most authors have reported that this device is not suitable for AO/OTA A3 reverse oblique or transverse fractures due to high incidence of fixation failures $(5,6)$. Intramedullary hip nailing for these fractures reportedly has less potential for cutout of the lag screw because of their loadbearing capacity when compared with extramedullary implants. Cephalomedullary nailing was introduced in the late 1980s for the treatment of trochanteric femoral fractures (7-9). However, clinical reports regarding intramedullary hip nailing for reverse obliquity intertrochanteric fractures are few in number (9-14). Despite improved techniques and various implant modifications, implant failure remains a challenging problem for these unstable fractures.

$\mathbf{A}$

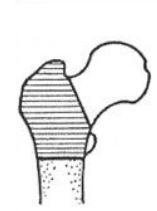

A

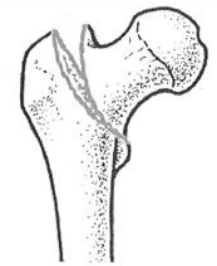

A1

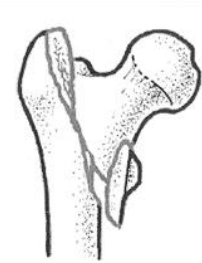

A2

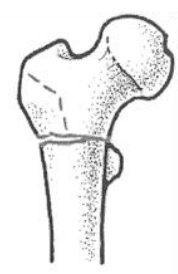

A3

B
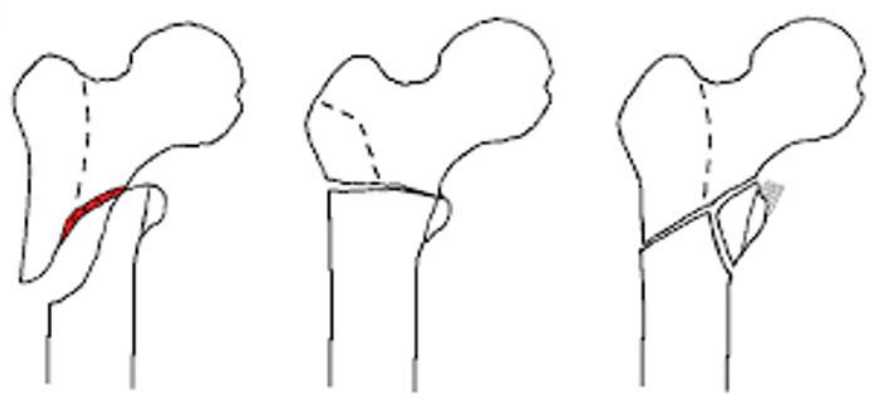

A3.1 Simple, oblique

A3.2 Simple, transverse

A3.3 With a medial fragment

Figure 1. Diagrams of AO/OTA 31-A fractures $(A)$ and of three subgroups of $A 3$ fractures (B).

The A1 (pertrochanteric) fractures are always two-part fractures with an intact posteromedial buttress. The A2 (pertrochanteric multifragmentary) fractures always have a posteromedial fragment involving the lesser trochanter and a varying amount of adjacent posteromedial cortex.

In both the $\mathrm{A} 1$ and $\mathrm{A} 2$ fractures, the primary fracture line runs from proximal-lateral to distal-medial.

The A3 fractures are intertrochanteric, with the fracture line exiting the lateral femoral cortex distal to the vastus ridge. In the reverse oblique form of A3 fractures, the primary fracture line runs from proximal-medial to distal-lateral.

(Reprinted from: Orthopaedic Trauma Association Committee for Coding and Classification.

Fracture and dislocation compendium. J Orthop Trauma. 1996;10(Suppl 1):31-2, 35. $)^{2}$

In this study, we present the results of intramedullary nailing surgery performed for reverse obliquity intertrochanteric of thirty two patients with AO/OTA 31-A3 fractures using standard or long Proximal Femoral Nail Antirotation (PFNA; Synthes, Oberdorf, Switzerland) and Gamma nail (Stryker, Mahwah, New Jersey, USA) available in our trauma centre during the period of 2012-2020 (15, 16). Proximal nailing surgery was performed for reverse obliquity intertrochanteric fractures in treatment of a non-pathologic fracture, using one lag screw proximally with one or two distal locking screws, and we evaluated the quality of the reduction, operative time, complications and functional status of the patients.

\section{The aim}

The aim of this study is to evaluate the outcome of the treatment of unstable reverse obliquity intertrochanteric fractures (with fracture line that runs distally in a medial to lateral direction) using the proximal cephalomedullary nails.

\section{Materials and methods}

Between 2012 and 2020, we treated 32 reverse oblique intertrochanteric fractures (type 31-A3 of the AO/OTA classification). 
We excluded patients with pathological fractures, fractures associated with polytrauma, a preexisting femoral deformity preventing hip screw osteosynthesis or intramedullary nailing, previous surgery on the ipsilateral hip or femur, and fractures extending $5 \mathrm{~cm}$ distally to the inferior border of the lesser trochanter.

We retrospectively recorded age, gender and distribution of the fractures subgroups in our series of patients. Patients were evaluated with perioperative complications, operation time, fluoroscopy time and duration of hospital stay. During a mean of 12.36 months (range 12-22), the results, as well as the intraoperative and postoperative complications, were noted. We recorded their ability to walk within their place of residence, their ability to walk outside, and their ability to go shopping independently or with external support. Operative and postoperative data included specific information on the intramedullary fixation device used, initial reduction of fracture and position of implant, as a radiographs of the affected hip at each follow-up visit, and any changes in the position of the implant and the extent of fracture union were noted. Radiological consolidation was defined when there were visible bone trabeculae between the fragments in the frontal and lateral radiographs. Delayed union was defined as the absence of radiological and clinical union four months after surgery and non-union after nine months. Malunion was defined by more than 10 degrees of varus or valgus deformity and more than $10 \mathrm{~mm}$ of shortening compared with the unaffected hip. Nonunion was defined as radiographic lucency around the implants, persistent fracture line that failed to show progressive healing after 9 months, loss of fixation, and pain associated with radiographic findings described above during walking at latest follow-up. Loss of fixation was defined as cutout or penetration of the blade into the joint or nail breakage.

\section{Treatment protocol}

All operations were performed with the patient in a supine position on an orthopedic fracture table. The operation was done using a C-arm fluoroscopy with an image intensifier in order to verify fracture reduction and fixation. All patients were given one dose $(1.5 \mathrm{~g})$ of prophylactic intravenous antibiotics (Primaceph, PharmaSwiss d.o.o.) and all patients were treated with low-molecular-weight heparin (Fragmin 5000 IU SC, Pfizer Manufacturing Belgium NV) beginning on the day of surgery for prophylactic anticoagulation continuing three weeks postoperatively, unless there was a medical contraindication to such treatments.

We used a minimally invasive technique through the lateral border of the tip of the greater trochanter, using guided fluoroscopy to achieve alignment by a closed reduction technique when possible. Fracture reduction was graded as anatomical, acceptable nonanatomical and poor. All the preand post-operative radiographs were reviewed (AP and lateral of the hip and femur), and the fracture reduction was considered to be "anatomical" when there was less than $4 \mathrm{~mm}$ of displacement between the major fragments and when the normal neckshaft angle had been re-established with less than 5 degrees of varus, valgus, anteversion or retroversion in the post reduction images seen on the Image intensifier. It was considered acceptable nonanatomical if the deviation was between 5-10 degrees and poor if it exceeded 10 degrees The ideal recommended screw tip position was in the inferior half of the femoral head as seen in the anteroposterior radiograph and in the central part of the head in the lateral radiograph, with the sum of the distances from the screw tip to the apex of the femoral head as measured on anteroposterior and on lateral views had to be less than $25 \mathrm{~mm}$.

\section{Follow-up protocol}

Postoperatively, all patients were encouraged to walk fully weight bearing assisted by external support as soon as possible after surgery. The patients were allowed to bear as much weight as they could tolerate. The patients were routinely examined at our outpatient clinic by an orthopedic doctor at 3 and 6 weeks, and at 3, 6, 12 months, and two years after the surgery, until fracture union was evident, as shown by the patient's anamnesis, physical examination and $\mathrm{X}$-ray. The fracture was considered to have healed when the fracture was filled with callus and hip movement and walking was painless.

\section{Statistical analysis}

Statistical analysis was performed using standard data processing programs - MS EXCEL and software package R. Tests were performed with Chisquare, Fisher's exact test and t-test for independent samples. A value of $p<0.05$ was considered as significant. Continuous variables were presented as mean \pm stdev or as median (range); categorical data were presented as number (\%). Student's t-test was used for determining any differences in age, operative and fluoroscopy times, and follow-up times between groups. Clinical and functional outcomes were assessed according to Harris hip score and Barthel activity score, respectively. We performed statistical analyses using SPSS1 Version 16.0 (SPSS Inc, Chicago, IL, USA). Details collected included pre- and postoperative mobility and patient residence, operative details, perioperative medical and orthopaedic complications, re-operations, follow-up details and radiographic findings. The primary outcome measure was fixation failure needing re-operation.

\section{Results}

The mean patient age was 78 (range: 47-95) years, with 18 female and 14 male patients, and the left side was affected in 20 cases. According to the AO-OTA classification, 11 fractures were of type 31A3.1, three were type 31-A3.2 and 18 type 31-A3.3. 
The distribution of the fractures in our series is included in Table 1.

The mean follow-up was 12.36 months (range 12-22), and all operations were performed within 4.45 days of injury. Closed reduction was achieved in 26 patients whilst six required open reduction and four of these required cerclage wire fixation. Fracture reduction was considered satisfactory acceptable nonanatomic in seventeen (53.12\%) patients and anatomical in fifteen (46.88\%) patients, while the position of the hip screw was correct in 28 (85\%). In our study, the amount of subtrochanternic extension of fracture line and femoral bowing was determined and decision regarding the usage of the standard or long proximal femoral nail. The long nail was taken to prevent the nail impinging against the anterior femoral cortex in four cases and in nine cases for subtrochanteric extension of fracture. In 19 patients we used the standard proximal femoral locking nail (Figure 2), and in 13 the long nail also with distal locking (Figure 3).

Table 1. Distribution of the three subgroups of $31 \mathrm{~A}-\mathrm{A} 3$ fractures according to gender

\begin{tabular}{|c|c|c||}
\cline { 2 - 3 } \multicolumn{1}{c|}{} & Male & Female \\
\hline \hline A3.1 Simple, oblique & $2(6.25 \%)$ & $2(6.25 \%)$ \\
\hline A3.2 Simple, transverse & $5(15.62 \%)$ & $7(21.87 \%)$ \\
\hline A3.3 With a medial fragment & $7(21.87 \%)$ & $9(28.12 \%)$ \\
\hline$\Sigma$ & $14(43.75 \%)$ & $18(56.25 \%)$ \\
\hline Total & \multicolumn{2}{|c|}{32} \\
\hline
\end{tabular}
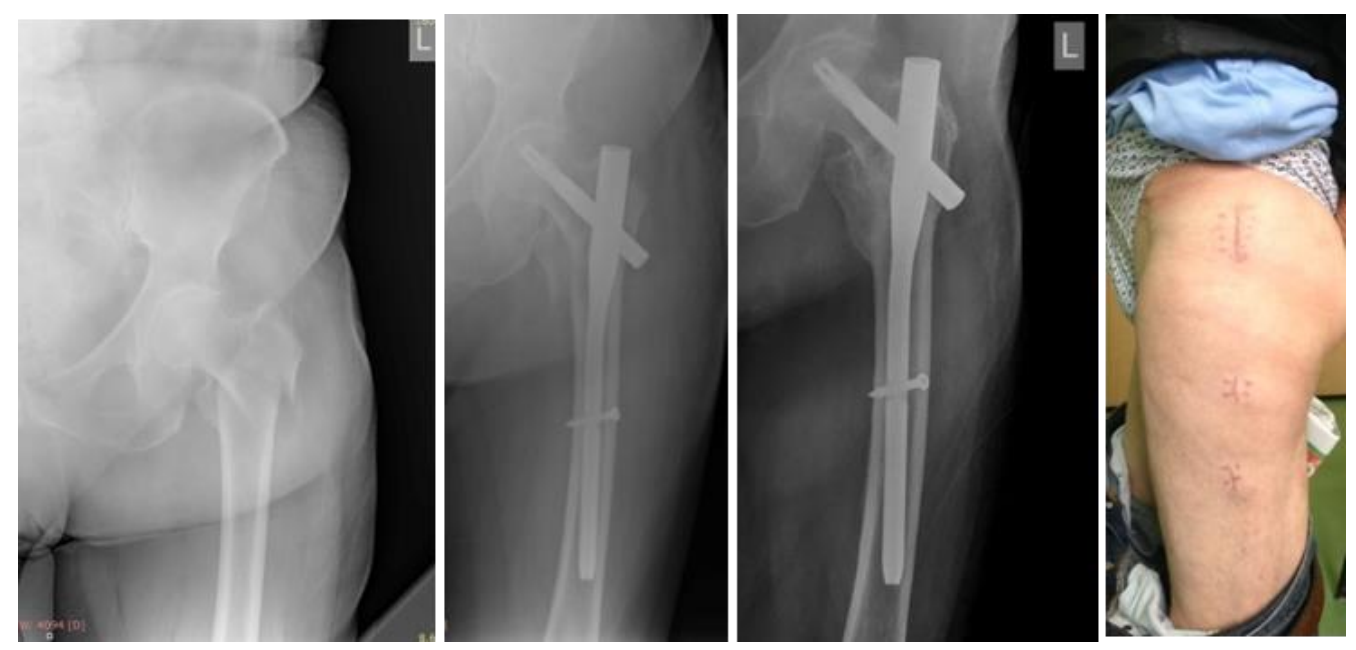

Figure 2. Images illustrate the case of a 68-year-old male patient with reverse oblique trochanteric fracture subtype 31A3-A3, treated with a standard (short) PFNA nail, using the closed method 

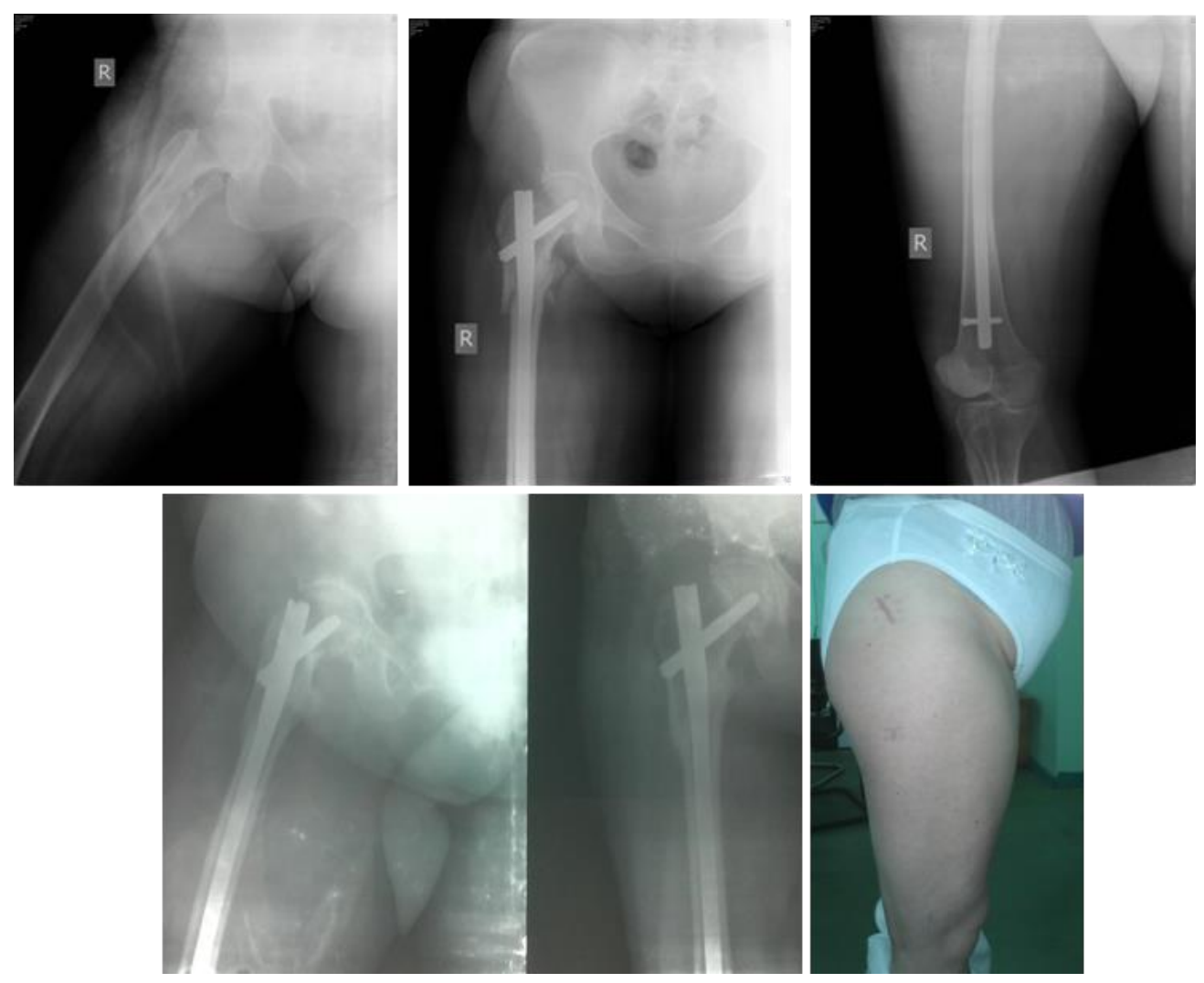

Figure 3. Images illustrate the case of a 47-year-old woman with reverse oblique trochanteric fracture subtype 31A3-A3, treated with a long gamma nail (GN), using the closed method

Comparison of demographic and perioperative data for reverse oblique fractures treated with standard (short) or long cephalomedullary nail in our series of patients revealed that values were comparable (Table 2).

There were no perioperative complications, but 14 patients developed one or more major com- plications during their hospital stay. These included heart failure, respiratory insufficiency and pulmonary or urinary infection. The average period of hospital stay was 5.2 (range: 2-11) days.

There were three major "orthopaedic" complications: late implant breakage, cutting-out and nonunion (Table 3).

Table 2. Demographic and perioperative data of patients with reverse oblique fractures of the proximal femur treated with standard or long proximal femoral nails

\begin{tabular}{|c|c|c|c|}
\hline Variable & Standard nail $(\mathrm{n}=19)$ & Long nail $(n=13)$ & p Value \\
\hline \multicolumn{4}{|l|}{ "Demographic } \\
\hline Age (years) * & $78(67-88)$ & $81(47-96)$ & 0.255 \\
\hline Sex (number of males/females) & $4 / 11$ & $4 / 14$ & 0.767 \\
\hline Side (number of right/left) & $7 / 8$ & $6 / 12$ & 0.493 \\
\hline Follow up (months) $*$ & $14(12-18)$ & $15(12-22)$ & 0.153 \\
\hline Operation time (minutes) $*$ & $52.6(34-65)$ & $71.8(57-94)$ & $<0.001$ \\
\hline Fluoroscopy time (seconds) $*$ & $58.6(45-79)$ & $75.3(56-103)$ & $<0.001$ \\
\hline Hospital stay (days) $*$ & $5.4(2-11)$ & $4.9(2-9)$ & 0.51 \\
\hline
\end{tabular}

* Values are expressed as mean, with range in parentheses 
Table 3. Summary of orthopaedic complications

\begin{tabular}{||l||l|l||}
\hline \multirow{3}{*}{ Major complications } & Malrotation & 2 \\
& Nonunion & 2 \\
& Late implant breakage & 1 \\
\hline \multirow{3}{*}{ Minor complications } & Locking bolts breaking & 2 \\
& Distal locking bolts backing out & 2 \\
& Breach of anterior femoral cortex & 1 \\
\hline
\end{tabular}

The mean Harris hip score was 74.66 (range 65-96) and the mean Barthel activity score was 15.71 (range 12-20). Nineteen patients had excellent results, nine had good results and four had poor results according to Harris hip score; three had low range, five patients had a median range and twentyfour patients had a high range of mobility according to the Barthel activity score. The mean duration of surgery was 64 minutes. The fractures healed in 29 patients; the average consolidation time was 8.6 weeks (range 7-13). In 19 patients (59\%) there was no pain after fracture consolidation, in 5 (16\%) there was slight pain that was controlled with analgesics and in three there was moderate pain. In one patient this was associated with radiographic hypertrophy of the anterior femoral cor tex at the distal tip of a long cephalomedullary nail. The pain disappeared after nail removal.

Four patients (12\%) were unable to walk, of whom three had Alzheimer's disease. Nineteen pa- tients (59\%) walked independently or with a single walking aid, five (16\%) needed two crutches and four $(12 \%)$ used a four-point walker. Fourteen patients (43\%) needed some assistance with daily activities, eight patients (26\%) needed continuous assistance and were living in residences for the elderly, and ten (31\%) were completely independent.

\section{Discussion}

There is a permanent confusion regarding the best treatment for fractures of the trochanteric region, especially in unstable reverse oblique fracture patterns of proximal femur. The results of extramedullary and intramedullary fixation of reverse oblique fractures in different studies are variable. The literature suggests that there is a huge range of failure rates for the same type of intramedullary nail used for the reverse oblique fracture (Table 4).

Table 4. Summary of clinical studies on reverse oblique fractures of the proximal femur

\begin{tabular}{|c|c|c|c|c|}
\hline Author & Year & $\begin{array}{c}\text { Number of } \\
\text { patients }\end{array}$ & Implant Type & Faliure rate $(\%)$ \\
\hline Hernandez-Vaquero $^{12}$ & 2005 & 47 & Gamma nail & 6.4 \\
\hline Min at al. ${ }^{14}$ & 2007 & 11 & Gamma nail & 27 \\
\hline Sadowski et al. ${ }^{9}$ & 2002 & 20 & Proximal Femoral Nail & 5 \\
\hline Honkonen et al. ${ }^{11}$ & 2003 & 36 & Proximal Femoral Nail & 14 \\
\hline Honkonen et al. ${ }^{15}$ & 2003 & 36 & Gamma nail & 3 \\
\hline Hernandez-Vaquero ${ }^{12}$ & 2005 & 47 & Gamma nail & 6.4 \\
\hline Min at al..$^{14}$ & 2007 & 11 & Gamma nail & 27 \\
\hline Sadowski et al. ${ }^{9}$ & 2002 & 20 & Proximal Femoral Nail & 5 \\
\hline Honkonen et al. ${ }^{11}$ & 2003 & 36 & Proximal Femoral Nail & 14 \\
\hline Min at al. ${ }^{13}$ & 2007 & 11 & Proximal Femoral Nail & 9 \\
\hline Park et al. ${ }^{13}$ & 2008 & 21 & Proximal Femoral Nail & 29 \\
\hline Ozkan et al. ${ }^{17}$ & 2010 & 15 & Proximal Femoral Nail & 0 \\
\hline Park et al. ${ }^{13}$ & 2008 & 19 & Intertrochanteric subtrochanteric nail & 0 \\
\hline Wang et al. ${ }^{25}$ & 2009 & 30 & Proximal Femoral Nail Antirotation & 3 \\
\hline Chou et al. ${ }^{22}$ & 2012 & 63 & Intramedullary hip screw & 7.9 \\
\hline Warschawski et al. ${ }^{18}$ & 2021 & 40 & Gamma nail & 20 \\
\hline
\end{tabular}


Most of the comparative studies have low numbers of patients and therefore drawing conclusions about relative superiority of one implant over another is inappropriate. Often the failure is due to inadequate fracture reduction, poorly placed femoral head screw or malpositioning of the implant. In our series, two fractures were poorly reduced and subsequently required revision surgery. Overall, in our series, four fractures were poorly reduced; therefore, the remaining two reduced in varus malalignment did, in fact, go to union. The total percentage of fixation failure in our series of patients was $6.25 \%$ (two patients). The relatively low number of patients in our series prevent the drawing of any firm conclusions with regard to the importance of fracture reduction. A review by Haidukewych et al. (17) of reverse oblique fractures demonstrated that poor implant placement and fracture malreduction had strong negative effect on the outcome. Almost every hip IMN has standard and long versions (varying from 30 to $42 \mathrm{~cm}$ ) for fixing the proximal part of femoral fractures. However, the indications for choosing either a standard or long IMN are somewhat unclear and usually subjective, and it is unclear whether long nails reduce the rates of reoperation and nonunion (18). It is well known that, when the nails were statically locked with two distal screws, the weak points were protected and the mechanical stresses were shifted towards the diaphyseal area, overloading the part of the nail close to the nonunion (19). Nevertheless, cephalomedullary nailing systems combine the biomechanical advantages of a sliding hip screw with those of intramedullary nailing. The sliding hip screw provides a controlled impaction of the fracture, leading to increased fracture stability, less collapse and decreased bone healing time. The intramedullary nail is located closer to the central weight bearing axis of the femur, reducing the bending stresses up to $30 \%$ due to smaller moment of inertia of the lag screw (20). Thus, in intertrochanteric fractures, the compression of both main fragments occurs along the femoral shaft axis, i.e., along the axis of the nail. With regard to anatomy of the proximal fragment, the lag screw passes almost through the lateral cortex of the proximal fragment. Therefore without distal locking, most of these fractures are rotationally and longitudinally unstable $(21,22)$. We used two screws distally in eleven patients (34.37\%) and one screw in twenty-one patients (65.63\%).

Secondary displacement of the system was considered when the screw changed its position inside the femoral head, and "cutting-out" of the screw was defined when the hip screw had penetrated into the acetabulum. Cutout, Z-effect or reversed Z-effect of the lag screws were scored as technical failures (23). Despite correct technical application, complications such as varus angulation of the proximal fragment and medialisation of the distal fragment during nail insertion, which may necessitate open reduction, may occur. Excessive loading of the femur may also occur due to distraction between the proximal and distal fragments that may cause stress fracture of the nail. This can be prevented with dynamic stabilisation or distal stabilisation of the nail after releasing the traction (24).

The use of cephalomedullary nailing systems has been complicated with implant breakage in only rare occasions. Breakages occurred mainly in complex unstable fracture patterns. In the literature, the mean time to implant breakage was 9 months (range 3-24 months), and all cases occurred after a period of several months of full weight bearing (25). In our study cases, we have one late implant breakage, 6 months postoperatively, due to nonunion at the fracture site. Possible biomechanical and/or biological causes of nail breakage could be attributable to (1) the initial inadequate primary reduction demonstrating varus axis deviation of the proximal fragment as the main cause for nail breakage, (2) use of the short standard nail to manage unstable intertrochanteric fractures with subtrochanteric extension, (3) the open reduction inducing devascularisation of the fragments or disturbance of the osteoinductive fracture hematoma, (4) the use of cerclage wiring which might compromise the periosteal vascularity, (5) the incorrect insertion point of the nail (the selection of the correct insertion point prevents the occurrence of varus axis deviation as well as the occurrence of shear forces) $(26,27)$. If those cannot be neutralized, secondary dislocation is inevitable.

In our study hardware or fixation failure was not related to the type of nail, implant material or subtype of AO/OTA $31-A 3$ fractures, but a neckshaft angle of $<125^{\circ}$ led to a significant increase in fixation failure. Thus, reverse trochanteric fractures require cautious follow-up studies to identify delayed or missing bone healing. In these cases of delayed or nonunion, additional treatment may include mobilization with partial weight bearing, dynamization of implant or even consequent operative revision using exchange nailing. In one case of late implant breakage in our series of patients, eight monts postoperative, we did the revision intervention using exchange nail surgical technique, and nonunion site healed inevitably 6 months after post revision surgery (Figure 4). 

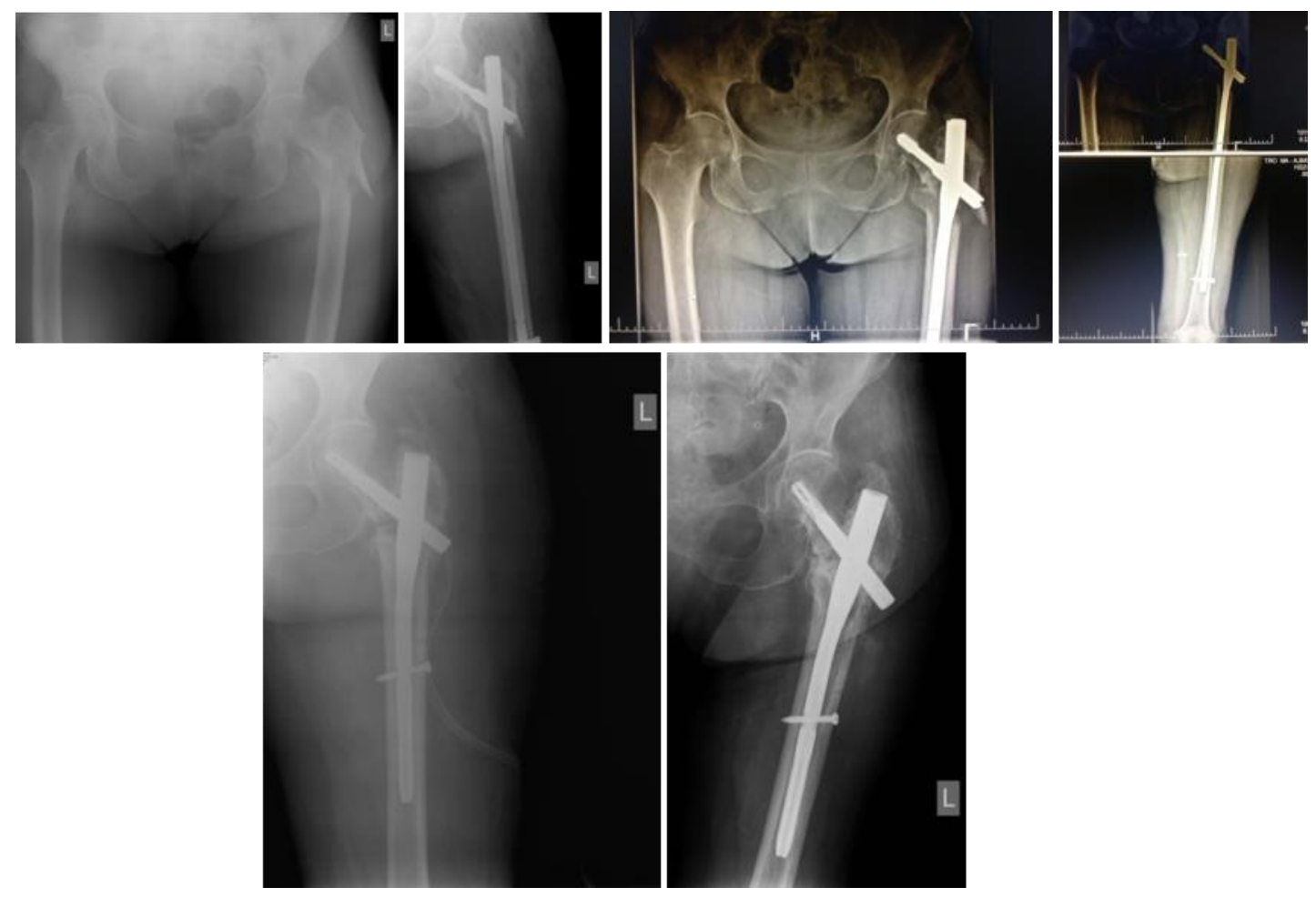

Figure 4. Images illustrate the case of a failure of the fixation, implant breakage 8 months postoperative in 81-year old female patient, treated primary with long gamma nail. $X$ rays after revision surgery using exchange nailing surgical technique with standard PFN nail and bone grafting of the nonunion site

The limitations of this study must be recognised. Limitations of our study are the lack of control group and relatively small patient population, but these are uncommon fractures accounting for $5-$ $23 \%$ of all trochanteric fractures even in the centralised trauma centres. It is a retrospective study carried out over a long period of time, potentially giving rise to inconsistencies in classification and treatment. Some of the CMN implants discussed in this study have now been upgraded and may not be in common use today, therefore making it difficult to make direct comparisons with the extramedullary implants. Further limitations include lack of rando- misation in selecting the implant type and length and a relatively small number of patients.

\section{Conclusion}

In spite of the limitations imposed by the retrospective study, we conclude, that the cephalomedullary devices are a good option for the treatment of reverse oblique intertrochanteric femoral fractures. We therefore recommend that surgeons aim to achieve good fracture reduction and use a long cephalomedullary implant device that they are familiar with to achieve ideal implant placement. 


\section{References}

1. Larsson S, Friberg S, Hansson LI. Trochanteric fractures. Mobility, complications, and mortality in 607 cases treated with the sliding-screw technique. Clin Orthop Relat Res 1990 Nov;(260):232-41. [PubMed]

2. Committee of Coding and Classification of the Orthopaedic Trauma Association. Fracture and dislocation compendium. J Orthop Trauma 1996;10(Suppl 1): 31-5. [PubMed]

3. Parker $\mathrm{MJ}$, Handoll $\mathrm{HH}$. Intramedullary nails for extracapsular hip fractures in adults. Cochrane Database Syst Rev. 2005 Apr 18;(2):CD004961. Update in: Cochrane Database Syst Rev 2006;(3):CD004961. [CrossRef] [PubMed]

4. Audigé L, Hanson B, Swiontkowski MF. Implantrelated complications in the treatment of unstable intertrochanteric fractures: meta-analysis of dynamic screw-plate versus dynamic screw-intramedullary nail devices. Int Orthop 2003;27(4):197-203. [CrossRef] [PubMed]

5. Willoughby R. Dynamic hip screw in the management of reverse obliquity intertrochanteric neck of femur fractures. Injury 2005 Jan;36(1):105-9.

[CrossRef] [PubMed]

6. Wagner R, Blattert TR, Weckbach A. Problemlösung der extraartikulären, koxalen Femurfraktur durch das "Gleitschrauben-Nagel-Prinzip". Ergebnisse zweier verschiedener Systeme (classic nail und gammaNagel) [Solution to the problem of extra-articular, femoral hip fracture by the "sliding screw-nail principle". Results of 2 different systems (classical nail and gamma nail)]. Unfallchirurg 1998 Dec;101(12): 894-900. [CrossRef] [PubMed]

7. Hoffmann $R$, Schmidmaier $G$, Schulz $R$, Schütz $M$, Südkamp NP. Classic-Nagel vs. dynamische Hüftschraube (DHS). Eine prospektiv-randomisierte Studie zur Behandlung pertrochantärer Femurfrakturen [Classic nail versus DHS. A prospective randomised study of fixation of trochanteric femur fractures]. Unfallchirurg 1999 Mar;102(3):182-90. German.

[CrossRef] [PubMed]

8. Bess RJ, Jolly SA. Comparison of compression hip screw and gamma nail for treatment of peritrochanteric fractures. J South Orthop Assoc 1997 Fall; 6(3):173-9. [PubMed]

9. Sadowski C, Lübbeke A, Saudan M, Riand N, Stern R, Hoffmeyer $P$. Treatment of reverse oblique and transverse intertrochanteric fractures with use of an intramedullary nail or a 95 degrees screw-plate: a prospective, randomized study. J Bone Joint Surg Am 2002 Mar;84(3):372-81. [PubMed]

10. Park SY, Yang KH, Yoo JH, Yoon HK, Park HW. The treatment of reverse obliquity intertrochanteric fractures with the intramedullary hip nail. J Trauma 2008 Oct;65(4):852-7. [CrossRef] [PubMed]

11. Honkonen SE, Vihtonen $K$, Järvinen MJ. Secondgeneration cephalomedullary nails in the treatment of reverse obliquity intertrochanteric fractures of the proximal femur. Injury 2004 Feb;35(2):179-83. [CrossRef] [PubMed]

12. Hernández-Vaquero $D$, Pérez-Hernández $D$, SuárezVázquez A, García-García J, García-Sandoval MA. Reverse oblique intertrochanteric femoral fractures treated with the gamma nail. Int Orthop 2005 Jun; 29(3):164-7. [CrossRef] [PubMed]

13. Ozkan K, Eceviz E, Unay K, Tasyikan L, Akman B, Eren A. Treatment of reverse oblique trochanteric femoral fractures with proximal femoral nail. Int Orthop 2011 Apr;35(4):595-8. [CrossRef] [PubMed]

14. Min WK, Kim SY, Kim TK, Lee KB, Cho MR, Ha YC, Koo $\mathrm{KH}$. Proximal femoral nail for the treatment of reverse obliquity intertrochanteric fractures compared with gamma nail. J Trauma 2007 Nov;63(5):1054-60. [CrossRef] [PubMed]

15. Simmermacher RK, Bosch AM, Van der Werken C. The AO/ASIF-proximal femoral nail (PFN): a new device for the treatment of unstable proximal femoral fractures. Injury 1999 Jun;30(5):327-32.

[CrossRef] [PubMed]

16. Bojan AJ, Beimel C, Speitling A, Taglang G, Ekholm C, Jönsson A. 3066 consecutive Gamma Nails. 12 years experience at a single centre. BMC Musculoskelet Disord 2010 Jun 26;11:133. [CrossRef] [PubMed]

17. Haidukewych GJ, Israel TA, Berry DJ. Reverse obliquity fractures of the intertrochanteric region of the femur. J Bone Joint Surg Am 2001 May;83(5): 643-50. [CrossRef] [PubMed]

18. Warschawski Y, Ankori R, Rutenberg TF, Steinberg EL, Atzmon R, Drexler M. Expandable Proximal Femoral Nail versus Gamma Proximal Femoral Nail for the treatment of hip reverse oblique fractures. Arch Orthop Trauma Surg 2021 Jan 8. [CrossRef] [PubMed]

19. Yoshino N, Watanabe $\mathrm{Y}$, Takenaka N, Watanabe $\mathrm{N}_{\text {, }}$ Fukuda Y, Fujita N, Maruyama N, Sumiyoshi H, Takai S. Implant failure of long Gamma nail in a patient with intertrochanteric-subtrochanteric fracture. J Orthop Sci 2006 Nov; 11(6):638-43. [CrossRef] [PubMed]

20. Kregor PJ, Obremskey WT, Kreder HJ, Swiontkowski MF. Unstable pertrochanteric femoral fractures. J Orthop Trauma 2014 Aug;28 Suppl 8:S25-8. [CrossRef] [PubMed]

21. Chou DT, Taylor AM, Boulton C, Moran CG. Reverse oblique intertrochanteric femoral fractures treated with the intramedullary hip screw (IMHS). Injury 2012 Jun;43(6):817-21. [CrossRef] [PubMed]

22. Baumgaertner $M R$, Curtin $S L$, Lindskog DM. Intramedullary versus extramedullary fixation for the treatment of intertrochanteric hip fractures. Clin Orthop Relat Res 1998 Mar;(348):87-94. [PubMed]

23. Yoshino N, Watanabe $\mathrm{Y}$, Takenaka N, Watanabe $\mathrm{N}$, Fukuda Y, Fujita N, Maruyama N, Sumiyoshi H, Takai S. Implant failure of long Gamma nail in a patient with intertrochanteric-subtrochanteric fracture. J Orthop Sci 2006 Nov;11(6):638-43. [CrossRef] [PubMed]

24. Wang $W$, Yang T, Fang $Y$, Wang G, Pu J, Liu L. [Treatment of reverse oblique fractures of intertrochanteric region of femur with proximal femoral nail antirotation]. Zhongguo Xiu Fu Chong Jian Wai Ke Za Zhi 2009 Nov;23(11):1306-10. Chinese. [PubMed]

25. Iwakura T, Niikura T, Lee SY, Sakai Y, Nishida $K$, Kuroda R, Kurosaka M. Breakage of a third generation gamma nail: a case report and review of the literature. Case Rep Orthop 2013;2013:172352. [CrossRef] [PubMed]

26. Najibi S, Mark L, Fehnel D. Mechanical failure of the long gamma nail in two proximal femur fractures. Iowa Orthop J 2010;30:205-10. [PubMed]

27. Van den Brink WA, Janssen IM. Failure of the gamma nail in a highly unstable proximal femur fracture: report of four cases encountered in The Netherlands. J Orthop Trauma 1995 Feb;9(1):53-6.

[CrossRef] [PubMed] 


\title{
PROKSIMALNI PRELOMI FEMURA SA OBRNUTOM KOSINOM (AO/OTA 31-A3) LEČENI METODOM INTRAMEDULARNE FIKSACIJE
}

\author{
Igor M. Kostić
}

Univerzitetski klinički centar Niš, Klinika za ortopedsku hirurgiju i traumatologiju, Niš, Srbija

Kontakt: Igor M. Kostić

Bulevar dr Zorana Đinđića 48, 18000 Niš, Srbija

E-mail: igaort@gmail.com

Intertrohanterni prelomi femura sa obrnutom kosinom su nestabilni prelomi jedinstvenih anatomskih i biomehaničkih karakteristika, koji se hirurški zbrinjavaju ekstramedularnim ili intramedularnim metodama fiksacije.

Cilj ove studije je procena efikasnosti primene metode proksimalne cefalomedularne fiksacije transtrohanternih preloma sa inverznom kosinom u odnosu na samu hiruršku proceduru, komplikacije i ishod lečenja.

Retrospektivno su analizirane primene proksimalne intramedularne fiksacije u hirurškom zbrinjavanju 32 bolesnika sa kosim, inverznim, intertrohanternim prelomima, koje su bile izvršene u periodu od 2012. do 2020. godine na Klinici za ortopediju i traumatologiju, UKC Niš. Postoperativno praćenje bolesnika kretalo se u rasponu od 12 meseci do 22 meseca $(12,36$ meseci).

Operativni zahvati izvedeni su u proseku 4,45 dana od povrede. Prosečno vreme trajanje hirurške intervencije iznosilo je 64 minuta. Zatvorena repozicija preloma i unutrašnja fiksacija postignute su u 26 slučajeva. Prihvatljiva anatomska repozicija postignuta je u 17 slučajeva $(53,12 \%)$, a anatomska repozicija u 15 slučajeva $(46,88 \%)$. Srednja vrednost Harris hip skora bila je 74,66 (65 - 96), a srednja vrednost Barthelovog skora aktivnosti iznosila je 15,71 (12 - 20). Zarastanje preloma nakon intramedularne fiksacije postignuto je u 29 slučajeva, dok su u 2 slučaja zabeležene komplikacije u vidu neuspeha unutrašnje fiksacije preloma i nezarastanja preloma $(6,25 \%)$.

Intramedularna fiksacija inverznih transtrohanternih preloma (AO/OTA 31 A3) kratkim ili dugim cefalomedularnim klinom obezbeđuje adekvatne biomehaničke uslove za zarastanje preloma u optimalnom vremenskom periodu, uz mogućnost izvođenja minimalno invazivne hirurške procedure.

Acta Medica Medianae 2021;60(4):45-54.

Ključne reči: inverzni transtrohanterni prelom, intramedularna fiksacija, minimalno invazivna hirurgija 